\title{
The Effects of RMB Internationalization on Balance of Payments in China
}

\author{
Yinghua Ren, Xiaomin Yuan, Wanru Zhao \\ College of Finance and Statistics \\ Hunan University \\ Changsha, China
}

\begin{abstract}
This study investigates the effect of RMB Internationalization on balance of payments (BOP) by using structural vector autoregressive model (SVAR) with data from January 2010 to December 2017. Empirical evidence shows that RMB Internationalization and RMB real effective exchange rate is the Granger causality of CA via interest rate. The appreciation of RMB real effective exchange rate is the main reason for the decease of the CA surplus in recent years. To FA, RMB internationalization shock is the most important source in the decrease of FA surplus. It indicates RMB exporting through FA is increasing as the acceleration of RMB internationalization. We further recommend that it is crucial for relevant departments to monitor the relationship between RMB Internationalization and the balance of BOP.
\end{abstract}

Keywords-RMB Internationalization; Balance of Payments (BOP); RMB real effective exchange rate; interest rate

\section{INTRODUCTION}

Maintain the balance of international payments (BOP) is one of the goals of macroeconomic policy management. In the standard framework of balance of international payments (BOP), the current account (CA) reflects the flows of goods, services transactions and all regular transfers, while the capital and financial account (FA) reflects the flows of asset ownership. In the case of no errors and omissions, and without considering the official intervention through foreign exchange reserves, the equation $\mathrm{CA}=-\mathrm{FA}$ is always set up. It means when CA is surplus, FA should match the corresponding deficit. Accordingly, the country will be a capital exporter, which is conducive to the circulation of its currency in foreign countries and the improvement of international status of the currency.

China's balance of payments (BOP) has kept double surplus in CA and FA for a long time, which can be observed from 2000 to 2011 in Fig.1. However, the CA maintains surplus and FA begins to deficit from 2012. Specially, the deficit of FA gets to 4853( $\$ 100$ million) and the ratio of the capital account balance to GDP (FA/GDP) gets to $-4.4 \%$ in 2015 . So, what're the main driving factors to the change of BOP structure in recent years?

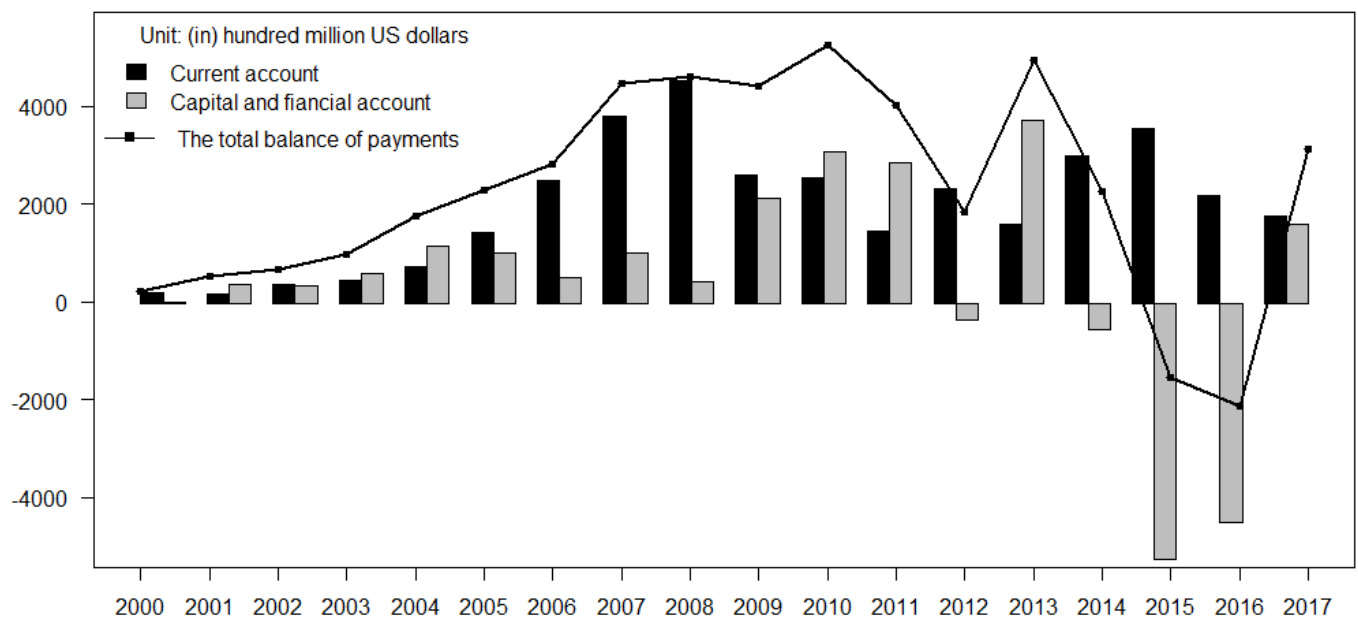

Fig. 1. The total balance of payments, current account balance, capital and financial account balance.

This work was supported by the National Social Science Fund Project under Grant [Project Number: 15BTJ009]. 
We investigate the questions in the paper. We focus on the reaction of the CA and FA to the shocks of driving factors from exchange rate, interest rate and RMB internationalization. As China began to carry out Pilot Reform of RMB settlement in cross-border trade, officially launched the RMB internationalization strategy since April 2009. RMB has been playing an increasingly important role in the international monetary system. RMB has joined in special drawing right (SDR) in 2016. Meanwhile, RMB internationalization is a higher level of economy opening process, which is closely related to the development of real economy and the improvement of financial market. At the same time, it is closely connected with China's current and capital account liberalization. With the improvement of RMB exchange rate formation mechanism and interest rate marketization, the elasticity of exchange rate and interest rate is gradually larger, and the fluctuations of exchange rate and interest rate will be more severe. Therefore, it is necessary to clarify the effect of driving factors on the change of BOP in China.

Previous studies mainly explained the double surplus of BOP for the following reasons: the export-oriented trade policy, RMB depreciation, official intervention of foreign exchange reserves and high saving rate in China (Feldstein 2011 [1]). In contrast to past studies, we have added RMB internationalization into the research framework and try to reveal how the driving factors affect BOP structure in China. With the strategy of RMB internationalization, RMB offshore assets tend to increase overseas. We believe that our findings would shed light on the related polices of RMB cross-border trade and capital control in China.

Most of the existing studies consider the source of international imbalance is from domestic economic structure (Çalışkan and Karimova, 2017 [2]). Iavorschia (2014) [3] claim that the stability of BOP depends on the value of imports and exports, the degree of efficiency and product competitiveness, the price level, international services and the international markets position.

To the factors of imbalance of BOP, many researches has found that exchange rate and interest rate are the main factors, but the opinion is inconsistent. McKinnon and Schnabl (2014) [4] argue that the total effect on China's net trade balance of any discrete appreciation of the RMB is thus ambiguous: exports fall and so do imports, because of negative investment and the consumption effects on income. Rose (1991) [5] utilizes the econometric method to estimate the trade balance equation of the five major Organization for Economic Cooperation and Development (OECD) countries. The results show that real exchange rate fluctuations have little effect on the trade balance. On the contrary, many scholars believe that exchange rate fluctuations have an expressly impact on the BOP (Auboin and Ruta, 2013 [6]; Asteriou et al. (2016) [7]). Das (2009) [8]makes use of the Lhasa-Samuelson model to find that the continued appreciation of the RMB will contribute to the realization of China's BOP. Hunegnaw and Kim (2017) [9] find a significant and positive relation between exchange rate and BOP in Pakistan Economy by using ARDL and Granger causality test.
As for the impact of interest rates on the BOP structure, most scholars believe the changes of interest rate mainly caused by the production cost not only directly lead to changes in export and trade balance, but also indirectly cause exchange rate fluctuations on the trade balance effect. Prasad and $\mathrm{Ye}$ (2011) [10] claim that the tight control of the nominal value of the RMB is related to the dollar still has the effect of hindering the independence of monetary policy and creating other adverse side effects that inhibit the rebalancing of the economy

Previous studies have not provided a systematic and up-todate picture of the relationship between RMB internationalization and BOP Structure. However many scholars have pointed that RMB internationalization is closely connected with China's current and capital account liberalization. The current and capital account liberalization have played a key role in the popular use of offshore RMB (Frankel, 2012 [11]; Craig et al., 2013 [12]; Mbatu, 2014 [13]; Funke et al., 2015 [14]). But the pace and sequence of FA liberalization should be heeded as well in order to ensure that its benefits outweigh the costs (Arora et al., 2012 [15]). However, Guan (2016) [16] argues that currency internationalization is not the solution to the imbalance problem of BOP or an antidote against weak points completely; internationalization of currency itself has two different problems, and the various paths of currency internationalization have different effects on the balance of international payments.

There is little literature focus on the linkage between BOP structure and RMB internationalization. So, it is crucial to explore the effect of driving factors on the change of BOP in China with the acceleration of RMB internationalization. These findings will highlight the sustainable development of foreign economy and maintain the balance of BOP in China.

The article continues as follows: Section 2 puts forward data and methodology. Section 3 presents the empirical results and discussion. The final section is conclusion.

\section{DATA AND METHODOlogy}

\section{A. Data}

To investigate the effect of driving factors on BOP structure in China, five variables are included in SVAR model. They are RMB internationalization, RMB exchange rate, interest rate, the current account balance (CA), and the capital and financial account balance (FA). Since China began to implement pilot reform of RMB settlement in cross-border trade from 2009, we use monthly data from January 2010 to December 2017.

Fig.2 demonstrates the trend of RMB internationalization by RMB global index (RGI) and RMB offshore deposit scale in Hong Kong (RMB) ${ }^{1}$. The two lines have the similar trend.

${ }^{1}$ The RMB global index RGI is a comprehensive index of RMB internationalization launched in November 2012 by Standard Chartered Bank. It covers four major RMB offshore markets, including Hong Kong and London, Singapore and Taiwan. Measuring the growth of four operations, including deposits (wealth stocks), dim sum bonds and certificates (financing instruments), trade settlements and other international payments (international trade) and foreign exchange (channels of exchange). 
As the RGI series is too short, we use RMB offshore deposit in Hong Kong to represent RMB internationalization, which is from the Hong Kong monetary authority's (quasi-central bank) monthly bulletin of financial data. Exchange rate is the RMB real effective exchange rate (REER) getting from Bank for International Settlements (BIS). The data regards 2010 as the base period $(2010=100)$, where the rise of the index represents the currency's appreciation and the decline of the index represents the depreciation. Interest rate is the 7-day inter-bank offered rate, SHIBOR in China (IR), which is obtained from Wind database.

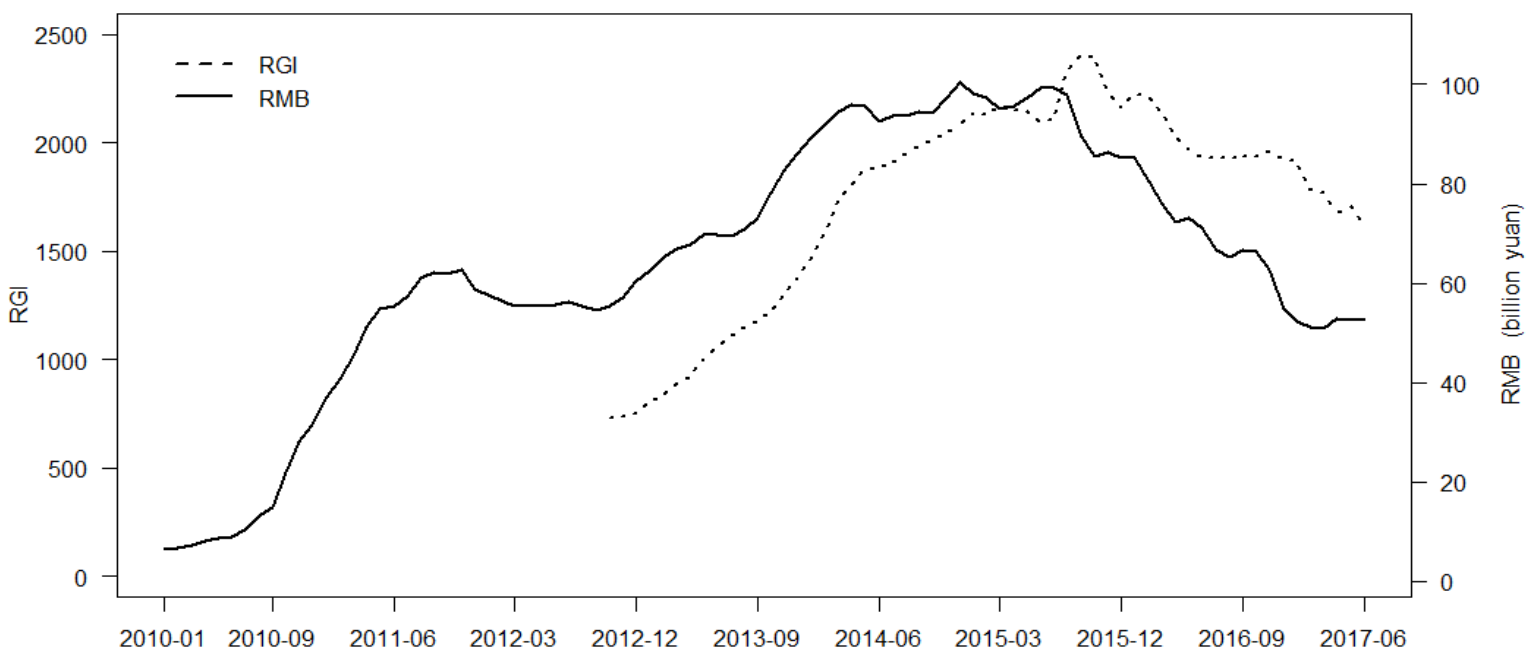

Fig. 2. The trend of RMB deposit in Hong Kong and RMB global index (RGI).

The VAR methodology that we employ requires the series to be stationary. Table I reports the descriptive statistics, ADF and PP tests. These tests show that RMB, REER, CA and FA are stationary after first difference, IR is stationary in level. Thus, the variables enter into the analysis with their first difference, except for interest rate. The CA balance (CA) and capital account balance (FA) are the representative of BOP. As China has published only the quarterly data of BOP since 2010, we convert quarterly data to monthly data by using Eviews8.0 software and the data obtained from China's State Administration of Foreign Exchange.

TABLE I. DESCRIPTIVE STATISTICS AND UNIT ROOT TESTS

\begin{tabular}{|c|c|c|c|c|c|c|c|c|c|c|c|c|}
\hline \multirow[b]{2}{*}{ Variable } & \multirow[b]{2}{*}{ Obs } & \multirow[b]{2}{*}{ Mean } & \multirow[b]{2}{*}{ S.E } & \multirow[b]{2}{*}{ Min } & \multirow[b]{2}{*}{ Max } & \multirow[b]{2}{*}{ Skew. } & \multirow[b]{2}{*}{ Kurt. } & \multirow[b]{2}{*}{$\begin{array}{c}\text { Jarque- } \\
\text { Bera }\end{array}$} & \multicolumn{2}{|c|}{$\mathrm{ADF}$} & \multicolumn{2}{|c|}{ PP } \\
\hline & & & & & & & & & Level & $\begin{array}{c}\text { First } \\
\text { difference } \\
\mathrm{d}\end{array}$ & Level & $\begin{array}{c}\text { First } \\
\text { difference } \\
\mathrm{d}\end{array}$ \\
\hline RMB & 96 & 63.432 & 25.142 & 6.395 & 100.356 & -0.576 & 2.917 & 5.329 & -2.433 & $-4.474 *$ & -2.355 & $-4.407^{*}$ \\
\hline REER & 96 & 114.972 & 10.125 & 97.960 & 130.990 & -0.120 & 1.846 & 5.557 & -1.316 & $-6.364 *$ & -1.570 & $-6.428^{*}$ \\
\hline IR & 96 & 3.321 & 0.948 & 1.520 & 6.980 & 0.802 & 4.483 & 19.087 & $-4.270^{*}$ & $-7.611^{*}$ & $-4.212 *$ & $-19.040 *$ \\
\hline $\mathrm{CA}$ & 96 & 113.643 & 55.504 & -7.688 & 218.751 & -0.042 & 2.043 & 3.691 & -0.654 & $-8.488^{*}$ & -1.098 & $-4.986^{*}$ \\
\hline FA & 96 & 6.057 & 184.952 & -378.773 & 316.744 & -0.354 & 2.169 & 4.760 & -1.849 & $-7.026^{*}$ & -2.123 & $-5.629^{*}$ \\
\hline
\end{tabular}

Note: $*$ represents the $1 \%$ significance level, respectively. 
B. Methodology
We employ the standard structural vector autoregressive model (SVAR) to investigate the effect of driving factors on BOP in China. The SVAR model is the following:

$$
A y_{t}=\Gamma_{1} y_{t-1}+\Gamma_{2} y_{t-2}+\cdots+\Gamma_{p} y_{t-p}+c+\mu_{t}
$$

Where $A=\left(\begin{array}{ccccc}1 & -a_{12} & -a_{13} & -a_{14} & -a_{15} \\ -a_{21} & 1 & -a_{23} & -a_{24} & -a_{25} \\ -a_{31} & -a_{32} & 1 & -a_{34} & -a_{35} \\ -a_{41} & -a_{42} & -a_{43} & 1 & -a_{45} \\ -a_{51} & -a_{52} & -a_{53} & -a_{54} & 1\end{array}\right), \Gamma_{i}=\left(\begin{array}{ccccc}\gamma_{11}^{i} & \gamma_{12}^{i} & \gamma_{13}^{i} & \gamma_{14}^{i} & \gamma_{15}^{i} \\ \gamma_{21}^{i} & \gamma_{22}^{i} & \gamma_{23}^{i} & \gamma_{24}^{i} & \gamma_{25}^{i} \\ \gamma_{31}^{i} & \gamma_{32}^{i} & \gamma_{33}^{i} & \gamma_{34}^{i} & \gamma_{35}^{i} \\ \gamma_{41}^{i} & \gamma_{42}^{i} & \gamma_{43}^{i} & \gamma_{44}^{i} & \gamma_{45}^{i} \\ \gamma_{51}^{i} & \gamma_{52}^{i} & \gamma_{53}^{i} & \gamma_{54}^{i} & \gamma_{55}^{i}\end{array}\right), y_{t}=(\Delta R M B, \Delta R E E R, I R, \Delta C A, \Delta F A)$

Where $y_{t}$ is the column vector of the five variables-

RMB internationalization, exchange rate, interest rate, $\mathrm{CA}$ and

FA. $c$ and $u_{t}$ represent constant and structural error terms

respectively. We assume the $u_{t}$ is serially uncorrelated, mutually orthogonal. The formula (1) is changed into a delay operator:

$$
A(L) y_{t}=u_{t}, \quad E\left(u_{t} u_{t}^{\prime}\right)=I_{k}
$$

Where $A(L)=A-\Gamma_{1} L-\Gamma_{2} L^{2}-\cdots-\Gamma_{p} L^{p}$ denotes the $\mathrm{k}$-th order parameter matrix of the causal operator. In general, where it is assumed that is reversible, the model can be transformed into equation (3):

$$
y_{t}=D(L) u_{t}
$$

Where

$$
D(L)=A(L)^{-1}=D_{0}+D_{1} L+\cdots+D_{P} L
$$

After obtaining the final model, we must identify the model; to better identify the model, we can translate it as follows:

$$
A \varepsilon_{t}=B \mu_{t}
$$

In order to satisfy the identification conditions of the SVAR model, there are two ways to set up short-term constraints. The one is Cholesky decomposition, the other is short-term constraints based on economic theory. Since the Cholesky decomposition will result in inconsistent and unstable results due to different order of variables, we set short-term constraints based on economic theory assumptions.

Assuming that the $\mathrm{B}$ matrix is a unit matrix, the diagonal elements of the A matrix are all 1 , which is equivalent to the fact that the constraint conditions have been imposed on the matrix. The identification of the contemporaneous relationships among variables in equation (5) is based on the following assumptions:

(a) As RMB internationalization is a long-term process, RMB internationalization do not respond to other shocks immediately.

(b) Due to the managed floating exchange rate mechanism and incomplete marketization of interest rates in China, exchange rate and interest rates do not contemporaneously respond to other shocks.

(c) According to the BOP theory, CA records real resources of international transactions, while FA records of asset ownership in international flow. So that CA and FA do not interact with each other in the current period.

We use the maximum likelihood estimation method to estimate the parameters of the model. More details on the estimation process can be found in online appendix.

\section{EMPIRICAL RESULTS AND DISCUSSION}

To examine the relation among RMB internationalization, exchange rate, interest rate, $\mathrm{CA}$ and FA, we employ a SVAR system to capture properly dynamic interactions. According to Schwarz information criterion (SC) and Hannan-Quinn criterion (HQ) values, the optimal model's lag order is 1 . The robust test of SVAR model also shows that all roots of the model in the unit circle is less than 1. The SVAR model is then used to conduct Granger causality tests. Wald tests are used to test the null hypothesis of no Granger causality. A small probability value ( $p$-value) of the Wald statistic rejects the null hypothesis of no feedback to the dependent variable and a large $\mathrm{p}$ value implies that the null cannot be rejected.

\section{A. Causality Test}

Table II shows the results of the pairwise Granger causality tests for the SVAR model. The first two rows reports p-values $(0.425$ and 0.017$)$ associated with the Granger causality tests between RMB internationalization and RMB exchange rate in the SVAR model. This suggests an unilateral causal link from $\mathrm{RMB}$ internationalization to RMB exchange rate. 
There is significant and bilateral links between the RMB and IR, and the RMB and FA separately. The Granger causality test of CA and RMB internationalization shows that there is no significant causal link between them. But interest rate Granger causes $\mathrm{CA}$ at the $5 \%$ level of significance. RMB and IR has the Granger causality between each other. Therefore, RMB internationalization is the Granger causality of CA via interest rate.
The Granger causality test of FA and REER shows that REER does Granger cause FA at the $10 \%$ level of significance. There is no significant causal linkage between FA and CA.

Taken as a whole, the results presented in Table 3 suggests that interest rate does Granger cause the change of $\mathrm{CA}$ at the significant level, RMB internationalization and RMB real exchange rate is the Granger causality of $\mathrm{CA}$ via interest rate variable. There is a bilateral causality between RMB internationalization and FA. RMB real exchange rate does Granger cause FA at the $10 \%$ level of significance.

TABLE II. PAIRWISE GRANGER CAUSALITY TESTS IN SVAR SYSTEM

\begin{tabular}{|lcrr|}
\hline Null Hypothesis: & Obs & F-Statistic & Prob. \\
\hline REER does not Granger Cause RMB & 94 & 0.85794 & 0.4275 \\
RMB does not Granger Cause REER & & 4.24164 & 0.0174 \\
\hline IR does not Granger Cause RMB & 94 & 3.15168 & 0.0476 \\
RMB does not Granger Cause IR & & 3.92102 & 0.0233 \\
\hline CA does not Granger Cause RMB & 94 & 0.50193 & 0.6071 \\
RMB does not Granger Cause CA & & 0.97785 & 0.3801 \\
\hline FA does not Granger Cause RMB & 94 & 6.36016 & 0.0026 \\
RMB does not Granger Cause FA & & 4.18740 & 0.0183 \\
\hline IR does not Granger Cause REER & 94 & 0.40579 & 0.6677 \\
REER does not Granger Cause IR & & 3.02148 & 0.0538 \\
\hline CA does not Granger Cause REER & 94 & 4.30902 & 0.0164 \\
REER does not Granger Cause CA & & 1.28575 & 0.2815 \\
\hline FA does not Granger Cause REER & 94 & 0.23452 & 0.7914 \\
REER does not Granger Cause FA & & 2.95637 & 0.0571 \\
\hline CA does not Granger Cause IR & 94 & 0.12509 & 0.8826 \\
IR does not Granger Cause CA & & 5.26090 & 0.0069 \\
\hline FA does not Granger Cause IR & 94 & 2.44279 & 0.0927 \\
IR does not Granger Cause FA & & 0.32182 & 0.7257 \\
\hline FA does not Granger Cause CA & 94 & 2.10098 & 0.1284 \\
CA does not Granger Cause FA & & 1.68005 & 0.1922 \\
\hline
\end{tabular}

\section{B. Responses of CA and FA to Driving Factors}

In this section, we investigate the responses of CA and FA to shocks of RMB internationalization, exchange rate and interest rate. Figure 3-6 illustrates the estimated results.

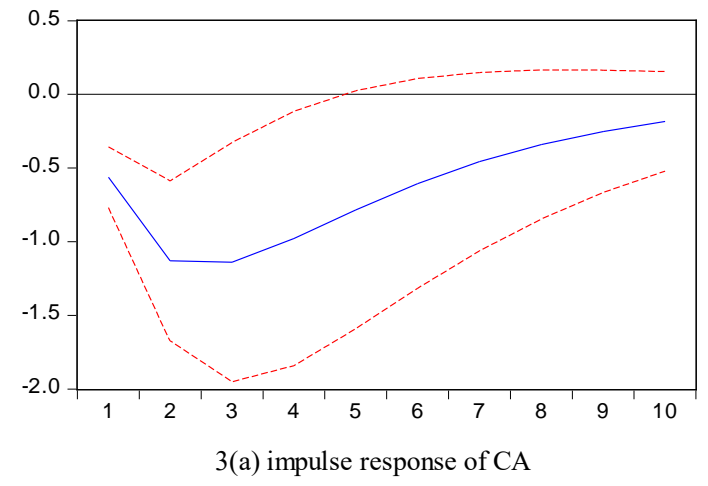

Fig. 3. Impulse response of $\mathrm{CA}$ and $\mathrm{FA}$ to RMB internationalization.

Fig. 3 presents the response of $\mathrm{CA}$ and FA to a 1 standard deviation increase in $\mathrm{RMB}$ internationalization. As clearly shown in Fig.3 (a), the expansion of RMB internationalization
1) Impulse response of $C A$ and $F A$ to $R M B$ internationalization.

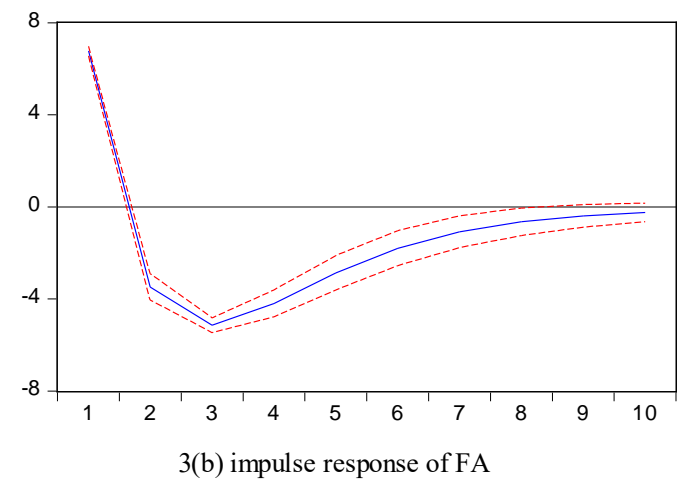

has a significant negative impact on $\mathrm{CA}$. This means that the surplus of CA decreases with the development of RMB internationalization. Actually, the ratio of CA to GDP gets 
$9.3 \%$ in 2008 , and then gradually decreases. It reaches $1.3 \%$ by the end of 2017(Table I). It might be explained from goods account, service account, income and current transfer account in CA.

The first is the decrease of surplus in goods account. The surplus of CA is mainly from the goods account, while the service account, income and current transfer account have always been in deficit ${ }^{2}$. China has established closer trade relations with East Asian economies since the completion of the China and ASEAN Free Trade Area (CAFTA) in 2010. RMB begin to be popular in East Asian countries and can be gradually accepted by the local people. Therefore the trade deficit has been widened in East Asian countries.

Second is the further deficit in service account. China has become the world's largest service trade deficit country. We attribute these to the large deficit in traditional projects such as tourism and transportation. With the advancement of RMB internationalization, China's service account deficit has continued to widen and has become an important factor in offsetting trade surpluses under the CA.

The third is about income and current transfer account. China's overseas investment is mainly financial investment, while direct investment is dominant foreign investment in China. As China's returns of the foreign investment (the cost of absorbing foreign investment) is much higher than other major economies, investment income project always has a big deficit. Considering the huge stock of overseas investment and foreign investment in China, it is difficult to adjust the investment structure in the short term, so the structural investment return deficit will continue for a period of time.

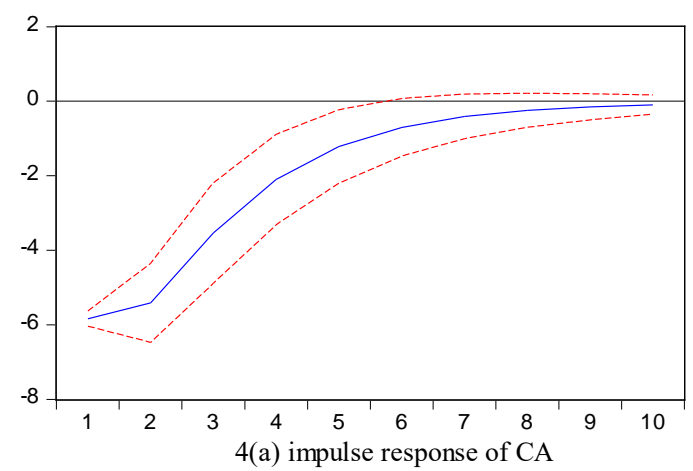

Fig. 4. Impulse response of $\mathrm{CA}$ and $\mathrm{FA}$ to exchange rate shock

As clearly shown in Fig.4(a), the structure shock of exchange rate induce a negative and significant response on $\mathrm{CA}$. This means that the appreciation of RMB real effective exchange rate can decrease the surplus of CA. Exchange rate volatility will arouse the fluctuation of import and export commodity prices, which will inhibit or stimulate the import and export commodities demand of domestic and foreign residents, thereby affecting the size of imports and exports and trade balance. When a country's currency exchange rate rises, the prices of imported goods are relatively lower, while the country's exported goods are relatively expensive in the international market. Consequently, it will stimulate imports and reduce exports, then cut the surplus of CA.
Fig.3 (b) shows that the structure shock of RMB internationalization has a positive impact on FA in the first period. But from the second period to the ninth period, the balance of FA maintains a significantly negative impulse response. It illustrates that the surplus of FA decreases to the shock of RMB internationalization in the long run. We can attribute these to the outflow of long-term and short-term capital flows respectively in the promotion of RMB internationalization process.

Direct investment in FA represents long-term capital flows. The difference between foreign direct investment (FDI) and overseas direct investment (ODI) is getting deficit in recent years. The scale of FDI remains basically stable in recent years. But In 2014, China's ODI has surpassed FDI, and China became the net exporter of capital for the first time. China's ODI reached 196.15 billion dollars for the first time in 2016, ranking second in the world. From the perspective of investment targets, China's ODI countries are highly concentrated. $84.2 \%$ of the investment stock is distributed in the developing economies, $14.1 \%$ in developed economies, and the other $1.7 \%$ in the transitional economies.

Securities investment in FA represents short-term capital flows. But for the arrival of the Fed's interest-rate cycle, the foreign exchange outflows under fixed-income investment and equity investment, which will reduce the surplus of FA.

To sum up, the surplus of CA and FA decrease to the shock of RMB internationalization. It's due to outward investment strategy of domestic enterprises or residents, and outflows in securities investment.

2) The effect of Exchange Rate and Interest Rate on the balance of CA and FA.

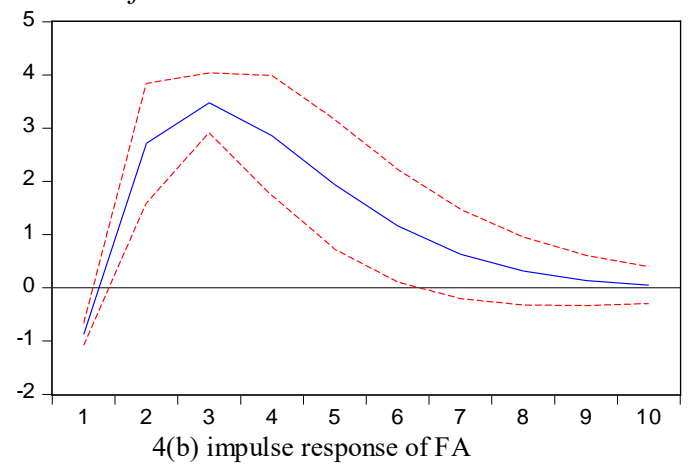

While Fig.4(b) shows that exchange rate has a negative impact on the FA in a short time. That means exchange rate and FA show the opposite change in the short term, and the depreciation of exchange rate will attract short term capital inflows. In the case of securities and other financial products, when the currency depreciates, foreign investors will expect the exchange rate to return to the original level in the future, if the other fundamental elements of the country have not changed. Therefore, foreign investors will buy the country's financial

${ }^{2}$ By the end of 2017, China's service trade deficit is 265.4billion dollars, of which the deficit for tourism project is 225.1 billion dollars and the deficit for transport. The deficit for transport project was 56.1 billion dollars. The deficit of the two projects has surpassed the overall deficit of service trade. 
assets after the current depreciation of the currency, in order to obtain a return after the appreciation of the currency in the

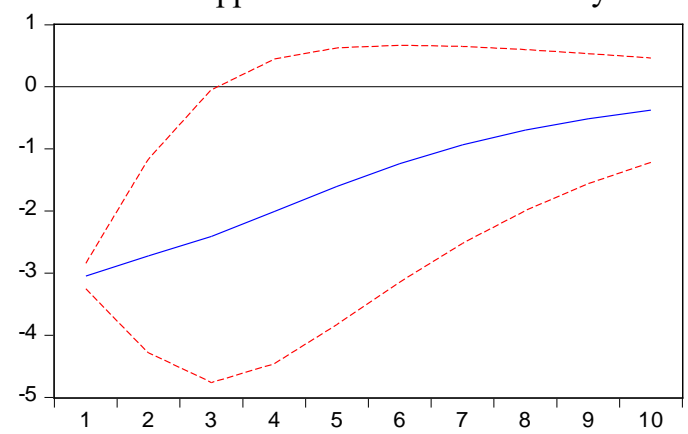

5(a) impulse response of CA

Fig. 5. Impulse response of $\mathrm{CA}$ and $\mathrm{FA}$ to interest rate.

Fig.5(a) shows that the positive effect of interest rates shocks on CA induce a negative response. While Fig.5(b) shows that interest rates has a positive impact on the FA in the 2-month period. If domestic interest rates rise, the demand for domestic currencies will increase, and the domestic currency will appreciate. Domestic products are more expensive than foreign products, therefore the net exports will decline, and so does the huge CA surplus. Additionally, the rising interest rates will increase the attractiveness of the RMB assets, thereby increasing short-term capital inflows, reducing short-term capital outflows and then promoting capital and financial surplus. Furthermore, an increase in interest rates will increase the cost of domestic currency loans, the number of local currency credit will decline, external loans will increase. All these will result in a surplus of FA.

\section{Contribution of Driving Factors to Variations in CA and FA}

To quantify the contribution of driving factors shocks to variations in $\mathrm{CA}$ and $\mathrm{FA}$, we employ variance decomposition future, which will bring short-term capital inflows.

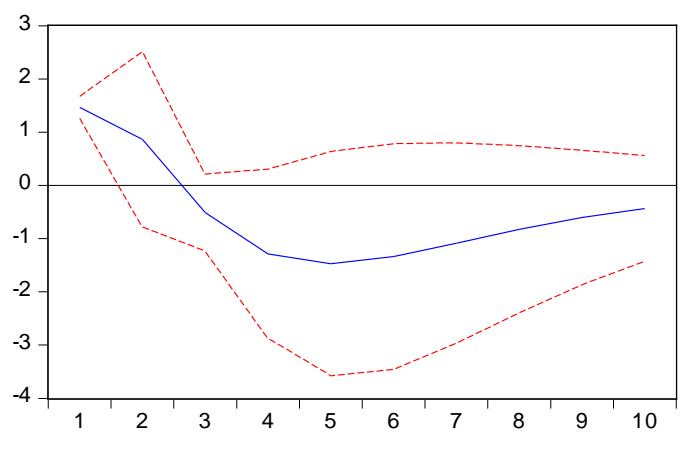

5(b) impulse response of FA

analysis. Table 4 depicts the variance decomposition results at forecasted horizons of 1,5 , and 10 months.

As shown the variations of $\mathrm{CA}$ is mainly explained by exchange rate, $\mathrm{RMB}$ internationalization and interest rate shocks at $12.76 \%, 1.43 \%$, and $1.25 \%$ respectively in the long term (10 months). Exchange rate is the main driving factor in the variation of CA. In contrast, the variations of FA is mainly explained by RMB internationalization (11.65\%). As shown, the contribution of RMB internationalization shocks to variations in FA is much greater than the other variables' shocks.

In addition to the contribution of RMB internationalization itself, $\mathrm{CA}$ and FA shocks explain the most variation in RMB internationalization in the long term. It illustrates that the mutual affective mechanism exists between RMB internationalization and BOP. Moreover, the mutual influence is significant. But the impact of $\mathrm{RMB}$ internationalization on the $\mathrm{BOP}$ is greater than the impact of $\mathrm{BOP}$ on $\mathrm{RMB}$ internationalization.

TABLE III. VARIANCE DECOMPOSITION

\begin{tabular}{|ccccccccc|}
\hline \multirow{2}{*}{$\begin{array}{c}\text { Shocks } \\
\text { Responses }\end{array}$} & period & SE & \multicolumn{7}{c}{ VDC } \\
\cline { 4 - 8 } & & & DRMB & DREER & IR & DCA & DFA \\
\hline \multirow{2}{*}{$D R M B$} & 1 & 2.091 & 100.000 & 0.000 & 0.000 & 0.000 & 0.000 \\
& 5 & 2.766 & 94.403 & 0.032 & 1.102 & 2.349 & 2.113 \\
& 10 & 2.782 & 93.974 & 0.052 & 1.309 & 2.476 & 2.189 \\
& 1 & 28.075 & 0.027 & 6.857 & 0.470 & 92.645 & 0.000 \\
DCA & 5 & 32.072 & 1.159 & 12.697 & 1.130 & 84.298 & 0.715 \\
& 10 & 32.166 & 1.425 & 12.760 & 1.251 & 83.810 & 0.753 \\
& 1 & 57.392 & 6.085 & 0.028 & 0.026 & 0.052 & 93.809 \\
& $5 F A$ & 66.520 & 11.247 & 1.051 & 0.063 & 5.006 & 82.633 \\
& 10 & 66.806 & 11.650 & 1.095 & 0.100 & 5.218 & 81.937 \\
\hline
\end{tabular}

b. Note: 'VDC' denotes the variance decomposition result and 'SE' denotes one-standard errors computed using 1000 bootstrap replications of the model 


\section{CONCLUSION}

Based on SVAR model, this paper provides a systematic and up-to-date picture of the response of CA and FA to the shocks from RMB real effective exchange rate, interest rate and $\mathrm{RMB}$ internationalization under the circumstance of RMB joining in SDR in 2016. Our findings indicate that shocks in $\mathrm{CA}$ and FA exert a significant decrease of the surplus of BOP in recent years. We summarise the findings of the paper and implications as follows.

RMB internationalization will significantly reduce the surplus of CA and FA. It means that the acceleration of RMB internationalization will promote the balance of BOP. And $\mathrm{RMB}$ internationalization shock is the most important source in the decrease of FA surplus. It indicates that as the loosen of capital account, it is easy for domestic enterprises or residents to invest abroad in an RMB-denominated manner.

Furthermore, RMB real effective exchange rate and interest rate changes remarkably affect $B O P$ structure. The appreciation of RMB real effective exchange rate is the main reason for the decease of the CA surplus in recent years. Additionally, the rise of interest rates will reduce the huge CA surplus, while it will result in a surplus of FA in a short time.

These findings may have important implications to the sustainability of BOP in China. Firstly, in the initial phase of the RMB internationalization, it requires BOP maintains surplus, and provides adequate international reserve for international payments and risk prevention. Only when the increase in reserve assets coming from the CA surplus (mainly trade accounts), can we really increase external net financial assets and external net financial claims. Thus, China's capacity for external liquidity increases. If the increase in reserve assets comes from the FA surplus, China's external net financial assets will not increase. Furthermore, large FA surplus is not conducive to widening the channels for RMB outflows.

Secondly, it is crucial and competitive to increase foreign exchange reserves and maintain the surplus of CA basis on the competitiveness of China's industries and products. So, we should speed up the adjustment of industrial and product structure, pay more attention to the technological progress of export products.

Thirdly, policy makers should pay more attention to the relationship between RMB internationalization and the balance of BOP in the process of capital opening. As the acceleration of RMB internationalization, the international market demand for RMB will increase. China will face two dilemma. On the one hand, it is necessary to maintain the stability of RMB's international value by maintain the balance or surplus of BOP. But it is difficult to meet the international market demand for local currency by exporting local currency. On the other hand, if China meets the international market demand for local currency by the deficit in BOP, which will endanger the value of RMB international market. To resolve the problems, it would be better to maintain a surplus in CA and a slight deficit in FA under the condition of the gross balance or surplus of BOP. To the surplus of CA, it should be better realized by the surplus of capital income and service income account at present, which also can make the CA balance or even surplus.
At this stage, the BOP surplus should mainly come from the CA surplus. Among them, investment returns is mainly driven through capital export and foreign investment, which is driven by the deficit in FA. The deficit in FA can be realized by RMB direct investment outside and provide loans to other developing countries. Exporting RMB by deficit in FA will increase the investment return in $\mathrm{CA}$, and increase the international circulation of $\mathrm{RMB}$ at the same time. Therefore, to maintain CA surplus and even a slight deficit in FA would be in line with the development of Chinese economy and RMB internationalization at the present stage.

\section{ACKNOWLEDGMENT}

This work was supported by the National Social Science Fund Project under Grant [Project Number: 15BTJ009].

\section{REFERENCES}

[1] Feldstein, M., 2011. The role of currency realignments in eliminating the US and China current account imbalances. NBER Working Papers 16674, National Bureau of Economic Research, Inc.

[2] Çalışkan, A., Karimova, A., 2017. Global Liquidity, Current account deficit and exchange rate balance sheet effects in Turkey. Emerging Markets Finance \& Trade 53:1619-1640. doi: 10.1080/1540496X.2016.1216837.

[3] Iavorschia, M., 2014. The influence of foreign direct investments and the current account of the balance of payments on the evolution of the Lei/Euro exchange rate in Romania. Procedia Economics \& Finance 16, 448-457.

[4] McKinnon, R.I., Schnabl, G., 2014, China's exchange rate and financial repression: the conflicted emergence of the Renminbi as an international currency. China \&World Economy 3, 1-35.

[5] Rose, A.K., 1991. The role of exchange rates in a popular model of international trade: does the "Marshall-Lerner" condition hold? Journal of International Economics 30, 301-316.

[6] Auboin, A., Ruta, M., 2013. The relationship between exchange rates and international trade: a literature review. World Trade Review 12 (3) : 577-605.

[7] Asteriou, D., Masatci, K., P1lbeam, K., 2016. Exchange rate volatility and international trade: international evidence from the MINT countries. Economic Modelling 58, 133-140.

[8] Das, D.K., 2009. The Evolution of Renminbi Yuan and the protracted debate on its undervaluation: an integrated review. Journal of Asian Economics 20, 570-579.

[9] Hunegnaw, F.B., Kim, S., 2017. Foreign exchange rate and trade balance dynamics in East African countries. The Journal of International Trade \& Economic Development (5):979-999. https:// doi.org/ 10.1080/ 09638199. 2017. 1327611.

[10] Prasad, E.S., Ye, L., 2011. The Renminbi's role in the global monetary system. Iza Discussion Papers 11, 199-206.

[11] Frankel, J., 2012. Internationalization of the RMB and historical precedents. Journal of Economic Integration 27(3), 329-365.

[12] Craig, R., Hua, C., Ng, P.K., Yuen, R., 2013. Development of the Renminbi market in Hong Kong SAR: assessing onshore-offshore market integration. IMF Working Papers 13(268), 1-24.

[13] Mbatu, R.S., 2014. Analysis on the path effect of the capital account liberalization in the process of currency internationalization. Studies of International Finance 29(5), 282-285.

[14] Funke, M., Shu, C., Cheng, X., Eraslan, S., 2015. Assessing the CNHCNY pricing differential: role of fundamentals, contagion and policy. Journal of International Money \& Finance 59(6), 245-262. 
[15] Arora, V., Habermeier, K., Ostry, J.D., Weeks-Brown, R., 2012. The liberalization and management of capital flows: an institutional view. International Monetary Fund 11, 1-48.
[16] Guan, T., 2016. Promote international balance of payments and internationalization of currency. The Contemporary World 2, 1-2. 